\title{
Umboniibacter marinipuniceus gen. nov., sp. nov., a marine gammaproteobacterium isolated from the mollusc Umbonium costatum from the Sea of Japan
}

Correspondence

Lyudmila A. Romanenko Iro@piboc.dvo.ru
Lyudmila A. Romanenko, ${ }^{1}$ Naoto Tanaka ${ }^{2}$ and Galina M. Frolova ${ }^{1}$

\author{
${ }^{1}$ Pacific Institute of Bioorganic Chemistry, Far-Eastern Branch, Russian Academy of Sciences, \\ 690022 Vladivostok, Prospect 100 Let Vladivostoku, 159, Russia \\ ${ }^{2}$ NODAI Culture Collection Center, Tokyo University of Agriculture, 1-1-1 Sakuragaoka, Setagaya-ku, \\ Tokyo 156-8502, Japan
}

The class Gammaproteobacteria includes a large cluster of halophilic, carbohydrate-degrading bacteria, including representatives of the genera Microbulbifer (Gonzalez et al., 1997), Saccharophagus (Ekborg et al., 2005), Teredinibacter (Distel et al., 2002), Endozoicomonas (Kurahashi \& Yokota, 2007) and Simiduia (Shieh et al., 2008), which have been described from marine or saline environments. At the time of writing, the genus Microbulbifer includes eight species, Microbulbifer hydrolyticus, the type species of the genus (Gonzalez et al., 1997), M. salipaludis (Yoon et al., 2003a), M. elongatus (Yoon et al., 2003b), M. maritimus (Yoon et al., 2004), M. celer (Yoon et al., 2007), M. halophilus (Tang et al., 2008), M. agarilyticus and M. thermotolerans (Miyazaki et al., 2008), which have been recovered from deep and intertidal sediments, seawater, solar salterns and saline soil. The carbohydrate-degrading bacterial group also includes

The GenBank/EMBL/DDBJ accession numbers for the 16S rRNA gene sequences of strains $\mathrm{KMM} 3891^{\top}$ and $\mathrm{KMM} 3892$ are $\mathrm{AB} 467279$ and AB467280.

Results of 2D TLC of polar lipids of strain KMM $3891^{\top}$ and a $16 \mathrm{~S}$ rRNA gene sequence-based maximum-likelihood tree are available as supplementary material with the online version of this paper. bacteria that are associated with marine biota, such as Saccharophagus degradans (Gonzalez \& Weiner, 2000; Ekborg et al., 2005), isolated from the salt-marsh grass Spartina alterniflora, and Endozoicomonas elysicola (Kurahashi \& Yokota, 2007), isolated from a marine mollusc. Teredinibacter turnerae (Distel et al., 2002) represents endosymbiotic micro-organisms that were retrieved from the gill tissue of a wood-boring mollusc, Lyrodus pedicellatus (Teredinidae), and are characterized by the ability to grow with cellulose as a sole carbon source and to fix nitrogen. The genus Cellvibrio is distantly related to the Microbulbifer/Saccharophagus group and includes Cellvibrio mixtus, the type species of the genus (containing the subspecies $C$. mixtus subsp. dextranolyticus and $C$. mixtus subsp. mixtus; Blackall et al., 1985), C. fibrivorans, C. gandavensis, C. ostraviensis (Mergaert et al., 2003), C. fulvus, C. vulgaris and C. japonicus (Humphry et al., 2003). Members of the genus Cellvibrio have been reported to be soil inhabitants and are known degraders of cellulose, dextran, chitin, starch or amylose.

In the course of studying the biodiversity of microorganisms associated with marine invertebrates, strains KMM $3891^{\mathrm{T}}$ and KMM 3892 were isolated from an internal tissue of the sand snail Umbonium costatum 
(Gastropoda, Trochidae) collected from sediment offshore from the Russian coast of the Sea of Japan. The novel isolates were Gram-negative, aerobic, faint pink-reddishpigmented, rod-shaped, non-motile, stenohaline and psychrotolerant bacteria that were unable to degrade most tested complex polysaccharides. Phylogenetic analysis based on 16S rRNA gene sequences placed the novel strains amongst the carbohydrate-degrading marine bacteria in the Gammaproteobacteria as a separate branch, and $16 \mathrm{~S}$ rRNA gene sequence similarity to their closest relatives, Microbulbifer species, E. elysicola, Simiduia agarivorans and T. turnerae, did not exceed $93 \%$. On the basis of distinctive phenotypic characteristics and phylogenetic distance, a novel genus and species are described to accommodate the strains.

Strains $\mathrm{KMM} 3891^{\mathrm{T}}$ and $\mathrm{KMM} 3892$ were isolated as described previously (Romanenko et al., 2004, 2007). They were grown aerobically on marine 2216 agar (MA) or marine broth $(\mathrm{MB})$ at $25-28{ }^{\circ} \mathrm{C}$ and stored at $-80{ }^{\circ} \mathrm{C}$ in liquid MB supplemented with $30 \%(\mathrm{v} / \mathrm{v})$ glycerol. Motility was observed by the hanging-drop method as described by Gerhardt et al. (1994). Gram staining, oxidase and catalase and hydrolytic reactions for gelatin, casein, chitin, CMcellulose, DNA and Tweens 20, 40 and 80 were tested according to the standard methods described by Smibert \& Krieg (1994). Hydrolysis of starch was determined after 2 days of incubation on MA containing $0.2 \%(\mathrm{w} / \mathrm{v})$ soluble starch by flooding the plates with $1 \%(\mathrm{w} / \mathrm{v})$ iodine solution. Formation of $\mathrm{H}_{2} \mathrm{~S}$ from thiosulfate was tested using a lead acetate paper strip. Acid production from carbohydrates was examined using the oxidation/fermentation medium of Leifson (1963) for marine bacteria. The ability of the strains to grow in the presence of organic substrates as sole carbon and energy sources was tested for 3 weeks on artificial seawater (ASW)-based medium supplemented with $0.2 \mathrm{~g} \mathrm{NH}_{4} \mathrm{Cl}$ and $0.05 \mathrm{~g}$ yeast extract $1^{-1}$ and $0.4 \%$ carbon source. Growth was considered as negative if it was equal to or less than that in the negative control to which any carbon source had not been added. The ASW contained $\left(1^{-1}\right) 30 \mathrm{~g} \mathrm{NaCl}, 4.9 \mathrm{~g} \mathrm{MgCl}_{2}, 3.9 \mathrm{~g}$ $\mathrm{Na}_{2} \mathrm{SO}_{4}, 1.1 \mathrm{~g} \mathrm{CaCl}_{2}, 0.66 \mathrm{~g} \mathrm{KCl}, 0.2 \mathrm{~g} \mathrm{NaHCO}_{3}, 0.096 \mathrm{~g}$ $\mathrm{KBr}, 0.026 \mathrm{~g} \mathrm{H}_{3} \mathrm{BO}_{3}, 0.024 \mathrm{~g} \mathrm{SrCl}_{2}$ and $0.003 \mathrm{~g} \mathrm{NaF}$ in distilled water. The ability of the strains to grow without additional organic growth factors and the requirement for sodium ions were respectively tested on the basal medium of Baumann \& Baumann (1981) supplemented with $0.1 \%$ glycerol, $0.1 \%$ potassium acetate and $0.1 \%$ potassium succinate and on basal medium in which sodium salts had been replaced by equimolar amounts of potassium salts. Requirement for and tolerance of $\mathrm{NaCl}$ was tested on ASW-based medium using various concentrations of $\mathrm{NaCl}$ in the range $0-20 \%$, supplemented with $\left(1^{-1}\right) 10.0$ g Bacto peptone, 2.0 g yeast extract, $0.028 \mathrm{~g} \mathrm{FeSO}_{4}$ and $15.0 \mathrm{~g}$ agar. Growth at different temperatures and $\mathrm{pH}$ and antibiotic resistance were studied as described previously (Romanenko et al., 2004, 2007). In addition, biochemical tests were carried out using API ZYM test kits
(bioMérieux) according to the manufacturer's instructions, except that the cultures were suspended in ASW. For polar lipid and fatty acid analyses, strains KMM $3891^{\mathrm{T}}$ and KMM 3892 were cultivated on MA at $28^{\circ} \mathrm{C}$ for 3 days and lipids were extracted using the chloroform/methanol extraction method of Bligh \& Dyer (1959). Polar lipids were analysed as described by Vaskovsky \& Terekhova (1979). Fatty acid methyl esters were obtained by alkaline methanolysis $(15 \%$ $\mathrm{NaOH} /$ methanol). The resultant fatty acid methyl esters were extracted with hexane and analysed using a GLC-MS Hewlett Packard model 6890 gas chromatograph equipped with an HP 5 MS $5 \%$ phenyl methyl siloxane capillary column $(30 \mathrm{~m} \times 250 \mu \mathrm{m} \times 0.25 \mu \mathrm{m})$ and connected to a Hewlett Packard model 5973 mass spectrometer. The pigments were extracted from cellular biomass using chloroform/methanol $(2: 1, \mathrm{v} / \mathrm{v})$ following hexane extraction. The visible spectra of extracts were analysed with a CECIL 7250 spectrophotometer. Cells of strains KMM $3891^{\mathrm{T}}$ and KMM 3892 for respiratory lipoquinone analysis were obtained from cultures grown in $\mathrm{MB}$ supplemented with casein hydrolysate at $25{ }^{\circ} \mathrm{C}$. Isoprenoid quinones were extracted using chloroform/methanol $(2: 1, \mathrm{v} / \mathrm{v})$, purified by preparative TLC on silica gel 60 ADAMANT plates (Fluka) and analysed by HPLC (Agilent 1100 Series) using a reversed-phase column (Hepersil ODS, $5 \mu \mathrm{m}$; $40 \times 250 \mathrm{~mm})$. Methanol/isopropanol $(65: 35)$ was used as the mobile phase and quinones were detected by monitoring the absorbance at $270 \mathrm{~nm}$. The DNA base composition was determined as described by Marmur \& Doty (1962) and Owen et al. (1969). The photobiotinlabelled DNA probe microplate method of Ezaki et al. (1989) was used to determine DNA relatedness between strains KMM $3891^{\mathrm{T}}$ and KMM 3892. The 16S rRNA gene sequences of strains KMM $3891^{\mathrm{T}}$ and KMM 3892, containing 1508 and $1502 \mathrm{nt}$, respectively, were determined as described by Shida et al. (1997). The sequences obtained were compared with 16S rRNA gene sequences retrieved from the EMBL/GenBank/DDBJ databases by using the FASTA program (Pearson \& Lipman, 1988). Phylogenetic analysis of $16 \mathrm{~S}$ rRNA gene sequences was performed using the software package MEGA 4 (Tamura et al., 2007) after multiple alignment of data by CLUSTAL_X (version 1.83; Thompson et al., 1997). Phylogenetic trees were constructed by the neighbour-joining and maximumparsimony methods and distances were calculated according to Kimura's two-parameter model. The robustness of phylogenetic trees was estimated by bootstrap analysis of 1000 replicates.

Cultural, physiological and metabolic properties are listed in Table 1 and in the genus and species descriptions. Strains KMM $3891^{\mathrm{T}}$ and KMM 3892 were similar in their phenotypic characteristics (except for differences in sensitivity to antibiotics and pigment absorption peaks) and their chemotaxonomic characteristics. The polar lipid profiles were identical and included phosphatidylethanolamine, phosphatidylglycerol and diphosphatidylglycerol (Supplementary Fig. S1, available in IJSEM Online). The 
Table 1. Differential characteristics for strains $\mathrm{KMM} 3891^{\top}$ and $\mathrm{KMM} 3892$ and members of related genera of the Gammaproteobacteria

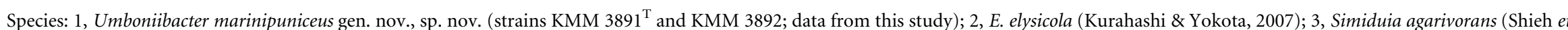

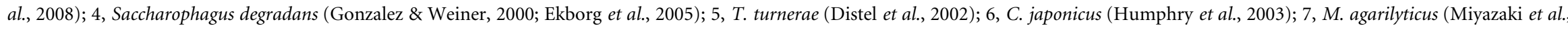

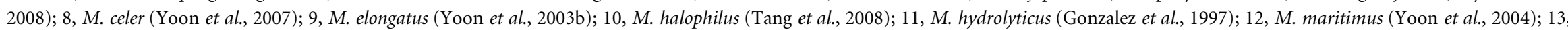
M. salipaludis (Yoon et al., 2003a); 14, M. thermotolerans (Miyazaki et al., 2008). +, Positive; -, negative; w, weak reaction; s, slow reaction; ND, no data available.

\begin{tabular}{|c|c|c|c|c|c|c|c|c|c|c|c|c|c|c|}
\hline Characteristic & 1 & 2 & 3 & 4 & 5 & 6 & 7 & 8 & 9 & 10 & 11 & 12 & 13 & 14 \\
\hline Colony colour ${ }^{\star}$ & PR & BG & Ow/C & BB & $\mathrm{T} / \mathrm{YB} \dagger$ & C & $\mathrm{C}$ & GY & ҮВ & YВ & C & YВ & GY & B \\
\hline Motility & - & + & $+\ddagger$ & + & + & + & - & - & + & + & - & - & - & + \\
\hline Growth at $4{ }^{\circ} \mathrm{C}$ & - & + & - & + & - & - & $\mathrm{ND}$ & - & ND & - & - & - & - & ND \\
\hline $\begin{array}{l}\text { Maximal growth } \\
\text { temperature } \\
\left({ }^{\circ} \mathrm{C}\right)\end{array}$ & 33 & 36 & 40 & 37 & 35 & 47 & $35-38$ & 48 & 38 & 45 & 41 & 48 & 45 & $52-54$ \\
\hline $\begin{array}{l}\mathrm{NaCl} \text { range for } \\
\text { growth }(\%)\end{array}$ & $2-5$ & $\mathrm{ND}$ & $0.5-7$ & $1-10$ & $0.6-3.6$ & $\mathrm{ND}$ & $\mathrm{ND}$ & $\mathrm{ND}$ & $\mathrm{ND}$ & $1-20$ & $0.6-6$ & ND & ND & $\mathrm{ND}$ \\
\hline $\begin{array}{l}\text { Tolerance of } \\
10 \% \mathrm{NaCl}\end{array}$ & - & $\mathrm{ND}$ & - & + & - & - & - & + & ND & + & - & + & + & - \\
\hline Nitrate reduction & - & + & + & + & $\mathrm{ND}$ & + & + & - & - & - & - & - & ND & + \\
\hline Acid from sugars & $\mathrm{w}$ & + & $\mathrm{ND}$ & + & + & + & + & + & + & + & - & + & + & + \\
\hline \multicolumn{15}{|l|}{ Hydrolysis of: } \\
\hline Gelatin & + & - & + & - & ND & - & + & - & + & + & + & + & ND & + \\
\hline Casein & S & $\mathrm{ND}$ & + & ND & ND & $\mathrm{ND}$ & + & + & ND & - & $\mathrm{ND}$ & + & $\mathrm{w}$ & + \\
\hline Tween 80 & + & $\mathrm{ND}$ & - & + & ND & - & + & + & ND & - & + & + & + & + \\
\hline Chitin & - & $\mathrm{ND}$ & + & + & ND & + & + & ND & + & $\mathrm{ND}$ & + & - & - & + \\
\hline Agar & - & $\mathrm{ND}$ & + & + & - & $\mathrm{ND}$ & + & - & + & $\mathrm{ND}$ & - & - & $\mathrm{w}$ & + \\
\hline Cellulose & - & ND & + & + & + & + & ND & ND & ND & ND & + & ND & ND & ND \\
\hline Starch & $\mathrm{w}$ & $\mathrm{ND}$ & + & + & $\mathrm{ND}$ & $\mathrm{ND}$ & + & + & $\mathrm{ND}$ & - & + & + & + & + \\
\hline Aesculin & - & - & + & ND & $\mathrm{ND}$ & + & - & + & ND & - & ND & - & + & + \\
\hline Tyrosine & - & ND & ND & + & ND & $\mathrm{ND}$ & ND & - & $\mathrm{ND}$ & ND & $\mathrm{ND}$ & + & $\mathrm{w}$ & $\mathrm{ND}$ \\
\hline Main fatty acids $§$ & $\begin{array}{c}\mathrm{C}_{17: 1} \omega 6 c \\
\mathrm{C}_{17: 0} \\
\mathrm{C}_{16: 0} \\
\mathrm{C}_{16: 1} \omega 7 c\end{array}$ & $\begin{array}{l}\mathrm{C}_{16: 1} \omega 7 c \\
\mathrm{C}_{16: 0}, \mathrm{C}_{14: 0}\end{array}$ & $\begin{array}{c}\mathrm{C}_{16: 1} \omega 7 c / \mathrm{i}-\mathrm{C}_{15: 0} \\
2-\mathrm{OH}, \mathrm{C}_{16: 0} \\
\mathrm{C}_{17: 1} \omega 8 c \\
\mathrm{C}_{18: 1} \omega 7 c\end{array}$ & $\begin{array}{l}C_{16: 0} \\
C_{14: 0}\end{array}$ & $\mathrm{ND}$ & $\begin{array}{l}\mathrm{C}_{16: 1} \\
\mathrm{C}_{18: 1} \\
\mathrm{C}_{16: 0}\end{array}$ & $\begin{array}{c}\mathrm{i}-\mathrm{C}_{15: 0} \\
\mathrm{i}-\mathrm{C}_{17: 1} \\
\mathrm{C}_{18: 1}\end{array}$ & $\begin{array}{l}\mathrm{i}-\mathrm{C}_{15: 0} \\
\mathrm{C}_{16: 0} \\
\mathrm{i}-\mathrm{C}_{17: 0}\end{array}$ & $\begin{array}{l}\mathrm{i}-\mathrm{C}_{15: 0} \\
\mathrm{i}-\mathrm{C}_{17: 1} \omega 9 c \\
\mathrm{C}_{18: 1} \omega 7 c\end{array}$ & $\begin{array}{l}\mathrm{i}-\mathrm{C}_{15: 0}, \\
\mathrm{i}-\mathrm{C}_{17: 0} \\
\mathrm{C}_{16: 0}, \mathrm{i}- \\
\mathrm{C}_{17: 1} \omega 9 \mathrm{c}\end{array}$ & $\begin{array}{c}\mathrm{i}-\mathrm{C}_{15: 0} \\
\mathrm{C}_{16: 0}\end{array}$ & $\begin{array}{l}\mathrm{i}-\mathrm{C}_{15: 0}, \\
\mathrm{i}-\mathrm{C}_{11: 0} \\
3-\mathrm{OH}, \\
\mathrm{i}-\mathrm{C}_{17: 1} \omega 9 c\end{array}$ & $\begin{array}{c}\mathrm{i}-\mathrm{C}_{15: 0} \\
\mathrm{C}_{16: 0}\end{array}$ & $\begin{array}{c}\mathrm{i}-\mathrm{C}_{15: 0}, \\
\mathrm{i}-\mathrm{C}_{16: 0}, \\
\mathrm{i}-\mathrm{C}_{17: 1}, \\
\mathrm{C}_{16: 1}, \mathrm{C}_{18: 1}\end{array}$ \\
\hline $\begin{array}{l}\text { DNA G + C } \\
\text { content }(\mathrm{mol} \%)\end{array}$ & 51.7 & 50.4 & 55.6 & 45.8 & $49-51$ & 53.3 & $55.2-55.3$ & 57.7 & ND & 63.2 & 57.7 & 59.9 & 59 & $56.0-56.2$ \\
\hline
\end{tabular}

${ }^{*}$ B, Brown; BB, black-brown; BG, beige; $\mathrm{C}$, cream; GY, greyish yellow; Ow, off-white; PR, pink-reddish; T, translucent; YB, yellowish brown.

$\dagger$ Pigmentation was reported to be age dependent (Distel et al., 2002).

$\ddagger$ Motile cells were rarely observed (Shieh et al., 2008).

Si, Iso-branched. 
presence of phosphatidylethanolamine, phosphatidylglycerol and diphosphatidylglycerol in the polar lipid composition is in line with profiles reported for Cellvibrio species (Humphry et al., 2003), Simiduia agarivorans (Shieh et al., 2008) and other marine gammaproteobacteria (Romanenko et al., 2003, 2004, 2005). Analysis of the respiratory lipoquinones revealed ubiquinone Q-7 as a major compound and trace amounts of Q-8 in both strains. Ubiquinone Q-7 alone or with Q-8 has been reported to be a major component for some Shewanella species (Venkateswaran et al., 1999). The novel strains were distinguished from their phylogenetic relatives in the predominance of ubiquinone Q-7, as E. elysicola contains the major ubiquinone Q-9 (Kurahashi \& Yokota, 2007), Simiduia agarivorans contains Q-10 together with MK-9 and MK-7 (Shieh et al., 2008) and M. elongatus, M. salipaludis, M. maritimus, M. halophilus, M. agarilyticus and M. thermotolerans contain Q-8 as the major ubiquinone (Yoon et al., 2003a, b, 2004; Tang et al., 2008; Miyazaki et al., 2008).

The fatty acid profiles of strains KMM $3891^{\mathrm{T}}$ and $\mathrm{KMM}$ 3892 contained $\mathrm{C}_{11: 0}$ (1.2 and $1.5 \%$, respectively), $\mathrm{C}_{12: 0}$ (4.0 and 5.7\%), $\mathrm{C}_{13: 0}\left(4.8\right.$ and 5.8\%), $\mathrm{C}_{14: 0}$ (4.2 and $4.8 \%), \mathrm{C}_{15: 0}(4.4$ and $5.2 \%), \mathrm{C}_{16: 0}(14.9$ and $14.0 \%)$, $\mathrm{C}_{17: 0}(13.9$ and $10.9 \%), \mathrm{C}_{18: 0}(2.5$ and $1.4 \%), \mathrm{C}_{10: 0} 3-\mathrm{OH}$ (1.7 and 2.3\%), $\mathrm{C}_{11: 0} 3-\mathrm{OH}(6.0$ and $4.7 \%), \mathrm{C}_{12: 0} 3-\mathrm{OH}$ (3.1 and $2.3 \%), \mathrm{C}_{15: 1}$ (1.0 and $\left.0.6 \%\right), \mathrm{C}_{16: 1} \omega 7 c(11.3$ and $11.6 \%), \mathrm{C}_{17: 1} \omega 6 c(21.6$ and $14.1 \%)$ and $\mathrm{C}_{18: 1} \omega 9$ (4.0 and $5.3 \%)$. The fatty acid compositions of strains KMM 3892 and $\mathrm{KMM} 3891^{\mathrm{T}}$ are characterized by the presence of large amounts of $\mathrm{C}_{17: 1} \omega 6 c, \mathrm{C}_{17: 0}, \mathrm{C}_{16: 0}$ and $\mathrm{C}_{16: 1} \omega 7 c$ (50.6 and $61.7 \%$ of the total, respectively) and the presence of the hydroxy fatty acids $\mathrm{C}_{10: 0} 3-\mathrm{OH}, \mathrm{C}_{11: 0} 3-\mathrm{OH}$ and $\mathrm{C}_{12: 0}$ $3-\mathrm{OH}$ (9.3 and $10.6 \%$, respectively). It should be noted that the predominant fatty acids $\mathrm{C}_{17: 1} \omega 6 c, \mathrm{C}_{17: 0}, \mathrm{C}_{16: 0}$ and $\mathrm{C}_{16: 1} \omega 7 c$ were each present in approximately equal amounts in both strains. As shown in Table 1, the fatty acid profiles of the novel bacteria differed substantially from those of Microbulbifer species in the absence of iso$\mathrm{C}_{15: 0}$, iso- $\mathrm{C}_{17: 0}$ and iso- $\mathrm{C}_{17: 1}$ (Gonzalez et al., 1997; Yoon et al., 2003a, b, 2004, 2007; Miyazaki et al., 2008; Tang et al., 2008), from that of Saccharophagus degradans in the absence of $\mathrm{C}_{12: 1} 3-\mathrm{OH}$ and $\mathrm{C}_{10: 0}$ (Gonzalez \& Weiner, 2000) and from that of E. elysicola in the absence of $C_{14: 1}$ $3-\mathrm{OH}$ and in the presence of $\mathrm{C}_{17: 1} \omega 6 c$ and $\mathrm{C}_{17: 0}$ (Kurahashi \& Yokota, 2007). The fatty acid profiles of strains KMM 3892 and KMM $3891^{\mathrm{T}}$ could be distinguished from that of C. japonicus (Humphry et al., 2003) in the minor content of $\mathrm{C}_{18: 1} \omega 9$ and in the significant amount of $\mathrm{C}_{17: 0}$. The fatty acid profiles of strains KMM 3892 and KMM $3891^{\mathrm{T}}$ were similar to that of Simiduia agarivorans (Shieh et al., 2008) in their major components, but differed in the presence of $\mathrm{C}_{11: 0}, \mathrm{C}_{12: 0}, \mathrm{C}_{11: 0} 3-\mathrm{OH}, \mathrm{C}_{13: 0}$ and $\mathrm{C}_{15: 0}$.

Polar lipids, ubiquinones and fatty acids have not been reported for T. turnerae (Distel et al., 2002).
It is clear that the combination of $\mathrm{C}_{17: 1} \omega 6 c, \mathrm{C}_{17: 0}, \mathrm{C}_{16: 0}$ and $\mathrm{C}_{16: 1} \omega 7 c$ as predominant fatty acids and the presence of hydroxy fatty acids makes the fatty acid compositions of the novel isolates KMM 3892 and $\mathrm{KMM} 3891^{\mathrm{T}}$ unique compared with those of their phylogenetic relatives, including Microbulbifer species, Saccharophagus degradans, E. elysicola, Simiduia agarivorans and C. japonicus.

The DNA G + C content of $51.7 \mathrm{~mol} \%$ determined for strain KMM $3891^{\mathrm{T}}$ clearly distinguished it from the members of the genus Microbulbifer (57.7-63.2 mol\%). This value is slightly higher than the $\mathrm{G}+\mathrm{C}$ content reported for Saccharophagus degradans (45.8 mol\%) but is lower than the values reported for C. japonicus $(53.3 \mathrm{~mol} \%)$ and Simiduia agarivorans ( $55.6 \mathrm{~mol} \%$ ); it falls within the range of $\mathrm{G}+\mathrm{C}$ contents found for T. turnerae (49-51 mol\%) and Endozoicomonas elysicola (50.4 mol\%) (Table 1). DNADNA relatedness of $90 \%$ was obtained for strains KMM $3891^{\mathrm{T}}$ and $\mathrm{KMM} 3892$, indicating their affiliation to the same species in accordance with the cut-off value of $70 \%$ recognized by Wayne et al. (1987) for the purpose of bacterial species discrimination.

Phylogenetic analysis based on 16S rRNA gene sequences showed that strains KMM $3891^{\mathrm{T}}$ and KMM 3892 formed a separate branch within the Gammaproteobacteria adjacent to E. elysicola (Kurahashi \& Yokota, 2007) (Fig. 1 and Supplementary Fig. S2). Their closest phylogenetic relatives were found to be the carbohydrate-degrading marine bacteria Saccharophagus degradans ( $92.7 \%$ sequence similarity to the type strain), M. salipaludis (92.3\%), $M$. hydrolyticus (92.1\%), M. agarilyticus (92.0\%), M. elongatus (91.6\%), M. celer (91.4\%), M. maritimus, M. halophilus, M. thermotolerans (all 91.2\%), C. japonicus (91.1\%), E. elysicola (91.0\%), T. turnerae (90.9\%) and Simiduia agarivorans $(90.4 \%)$. It is interesting to note that the novel mollusc isolates clustered with E. elysicola MKT110 ${ }^{\mathrm{T}}$, which was isolated from the gastrointestinal tract of the sea slug Elysia ornata, collected in seawater off Izu-Miyake Island, Japan, at a depth of $15 \mathrm{~m}$ (Kurahashi \& Yokota, 2007). The ability to decompose complex polysaccharides has been not reported for E. elysicola (Kurahashi \& Yokota, 2007). Strains KMM $3891^{\mathrm{T}}$ and KMM 3892 are likely to be very tightly associated with their host mollusc Umbonium costatum, as they displayed characteristic physiological and metabolic properties and a unique phylogenetic position. In addition, we failed to detect the same or similar bacteria in the surrounding seawater or sediment samples.

The novel strains are phylogenetically distantly related to $E$. elysicola, sharing only $91.0 \% 16 \mathrm{~S}$ rRNA gene sequence similarity, and can be distinguished by a combination of phenotypic and chemotaxonomic traits (Table 1). The isolated phylogenetic position of strains $\mathrm{KMM} 3891^{\mathrm{T}}$ and KMM 3892 is supported by their unique physiological and biochemical properties. The isolates were Gram-negative, aerobic, non-fermentative, heterotrophic, halophilic, stenohaline, faint pink-reddish-pigmented, non-motile, rodshaped bacteria. They could be distinguished from their 


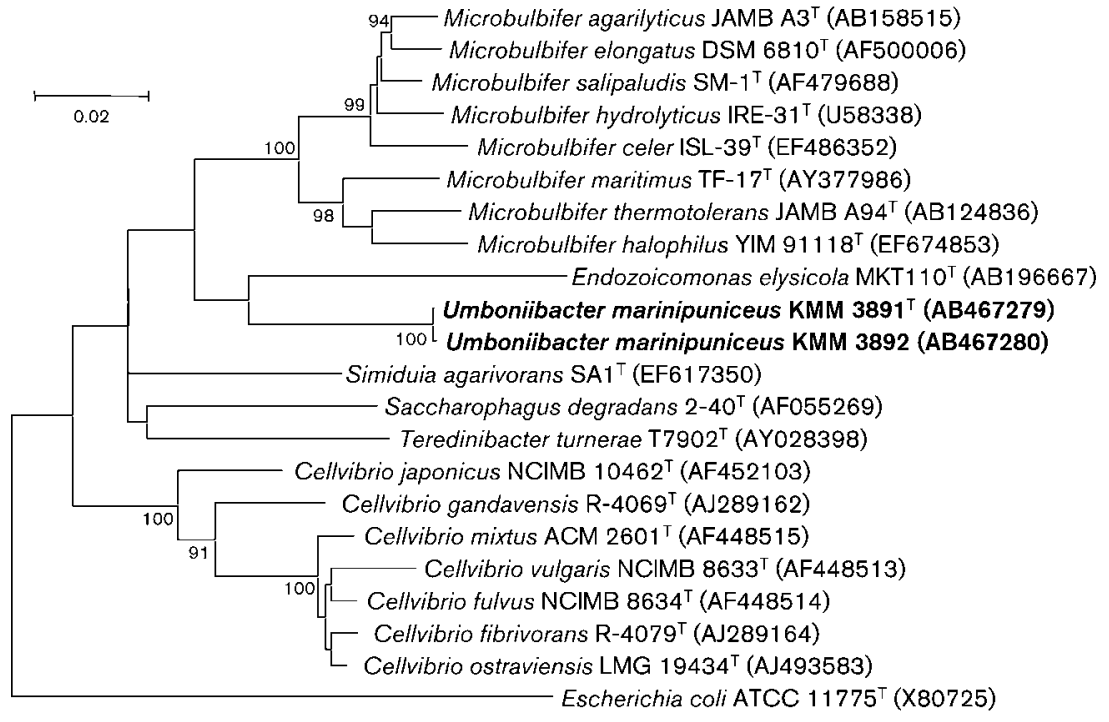

Fig. 1. Neighbour-joining phylogenetic tree based on 16S rRNA gene sequences available from the GenBank/EMBL/DDBJ databases (accession numbers in parentheses) showing the relationships of isolates $\mathrm{KMM} 3891^{\top}$ and KMM 3892 and related members of the Gammaproteobacteria. Phylogenetic analysis was performed using the software package MEGA 4 (Tamura et al., 2007) after multiple alignment of the data by CLUSTAL_X (version 1.83; Thompson et al., 1997). Bootstrap values based on 1000 replications are given as percentages at branching points; only values greater than $90 \%$ are shown. Bar, 0.02 substitutions per nucleotide position. close relatives belonging to the genera Saccharophagus, Microbulbifer, Teredinibacter, Endozoicomonas and Simiduia and C. japonicus in their minimal and maximal growth temperatures, salinity range for growth and metabolic properties and in not being able to degrade most tested polysaccharides, including agar, cellulose and chitin (Table 1). The strains exhibited only weak amylolytic activity. Starch hydrolysis determined by plating on agar medium was recorded as weak because the clearance zones that formed around bacterial spots were barely visible. Strains KMM $3891^{\mathrm{T}}$ and KMM 3892 produced proteolytic enzymes in routine and API ZYM tests as displayed in Table 1 and in the species description. Characteristics that differentiate strains KMM $3891^{\mathrm{T}}$ and KMM 3892 from related gammaproteobacteria are listed in Table 1.

On the basis of phenotypic and phylogenetic evidence, strains KMM $3891^{\mathrm{T}}$ and KMM 3892 could not be assigned to any known species or genus within the Gammaproteobacteria; we therefore propose to classify strains KMM $3891^{\mathrm{T}}$ and KMM 3892 within a novel genus and species, as Umboniibacter marinipuniceus gen. nov., sp. nov.

\section{Description of Umboniibacter gen. nov.}

Umboniibacter (Um.bo.ni.i.bac'ter. N.L. n. Umbonium scientific name of a genus of marine mollusc; N.L. masc. n. bacter rod; N.L. masc. n. Umboniibacter a rod from Umbonium, referring to the isolation of the first strains from the sand snail $U$. costatum).

Gram-negative, aerobic, oxidase-positive, weakly catalasepositive, rod-shaped bacteria. Chemo-organoheterotrophic. Sodium ions are essential for growth. The predominant isoprenoid quinone is Q-7. Polar lipids include phosphatidylethanolamine, phosphatidylglycerol and diphosphatidylglycerol. The major fatty acids are $\mathrm{C}_{17: 1} \omega 6 c, \mathrm{C}_{17: 0}, \mathrm{C}_{16: 0}$ and $\mathrm{C}_{16: 1} \omega 7 c$. The DNA G $+\mathrm{C}$ content of the type strain of the type species is $51.7 \mathrm{~mol} \%$ (thermal denaturation method). On the basis of $16 \mathrm{~S}$ rRNA gene sequence analysis, the genus represents a separate branch within the Gammaproteobacteria, related to the genera Endozoicomonas, Simiduia and Microbulbifer. Known strains have been isolated from the marine environment. The type species of the genus is Umboniibacter marinipuniceus.

\section{Description of Umboniibacter marinipuniceus sp. nov.}

Umboniibacter marinipuniceus (ma.ri.ni.pu.ni'ce.us. L. masc. adj. marinus marine; L. masc. adj. puniceus purple, red; N.L. masc. adj. marinipuniceus marine and red).

In addition to the properties given in the genus description, the species is characterized as follows. Cells are $0.4-0.6 \mu \mathrm{m}$ in diameter and 1.5-2.5 $\mu \mathrm{m}$ long. Non-motile. Colonies on MA are faint pink-reddish pigmented, transparent, smooth and shiny with regular edges, $2-3 \mathrm{~mm}$ in diameter. Abundant growth is observed on/in MA or MB supplemented with casein hydrolysate and media containing natural or artificial seawater supplemented with $0.5 \%(\mathrm{w} / \mathrm{v})$ peptone, tryptone or meat hydrolysate. No growth on basal medium supplemented with $0.1 \%$ glycerol, $0.1 \%$ potassium acetate and $0.1 \%$ potassium succinate or on basal medium when sodium salts are replaced by equimolar amounts of potassium salts. Weak growth when D-glucose or a mixture of amino acids (L-alanine, L-asparagine, L-arginine, L-phenylalanine, L-lysine, L-leucine, L-valine and L-histidine) is added. No growth on TSA, nutrient agar or R2A. Requires $\mathrm{NaCl}$ for growth; growth occurs at $2-5 \% \mathrm{NaCl}(\mathrm{w} / \mathrm{v})$ (optimum 2.5-3\%). Weak growth in 2 and $5 \% \mathrm{NaCl}$. Grows well in/on peptone medium containing $\mathrm{NaCl}$ alone without addition of any of the components of sea salts $\left(\mathrm{MgCl}_{2}, \mathrm{KCl}\right.$, $\mathrm{CaCl}_{2}, \mathrm{NaNO}_{3}, \mathrm{~K}_{2} \mathrm{HPO}_{4}, \mathrm{KCl}, \mathrm{NaSO}_{4}, \mathrm{NaHCO}_{3}, \mathrm{NaF}$ or $\mathrm{FeSO}_{4}$ ). Psychrotolerant; temperature range for growth is $5-33{ }^{\circ} \mathrm{C}$ with optimum growth at $25-28{ }^{\circ} \mathrm{C}$. Weak or no growth at $4{ }^{\circ} \mathrm{C}$, slow growth at $5{ }^{\circ} \mathrm{C}$ and no growth above 
$33{ }^{\circ} \mathrm{C}$. Grows at $\mathrm{pH} 6.5-10.0$, with optimum growth at $\mathrm{pH}$ 8.0-8.5. Negative for $\mathrm{H}_{2} \mathrm{~S}$ production. Positive for hydrolysis of gelatin and Tweens 20,40 and 80. Casein is hydrolysed within 3-5 days. Starch is hydrolysed weakly; clearance zones around bacterial spots on starch-containing agar are barely visible. Does not degrade CM-cellulose, agar, chitin or DNA. On L-tyrosine-containing medium, does not produce melanin-like pigments and/or clearance zones. Strain-dependent weak acid production is observed from D-glucose and maltose; the type strain is positive for D-glucose and negative for maltose. No acid formed from sucrose, lactose, D-galactose, D-mannose, cellobiose, D-xylose, L-arabinose, L-rhamnose, D-sorbitol or D-mannitol. In API 20NE tests, positive for gelatin hydrolysis and the PNPG test and negative for nitrate reduction, indole production, glucose acidification, arginine dihydrolase, urease production, aesculin hydrolysis and assimilation of substrates that are included in the API 20NE strip. Weak growth on D-glucose, maltose, sucrose, D-mannitol, citrate, L-alanine, L-asparagine, L-arginine, L-phenylalanine, L-valine and L-lysine in routine tests. No growth on D-xylose, Dgalactose, $\mathrm{N}$-acetylglucosamine, lactose, melibiose, raffinose, L-rhamnose, L-arabinose, D-ribose, D-mannose, cellobiose, glycerol, acetate, glutamic acid or DL-methionine. In API ZYM tests, positive for alkaline phosphatase, esterase (C4), esterase lipase (C8), leucine arylamidase, valine arylamidase, cystine arylamidase, $\alpha$-chymotrypsin, acid phosphatase, naphthol-AS-BI-phosphohydrolase and $N$-acetyl- $\beta$-glucosaminidase and negative for lipase (C14), trypsin, $\alpha$-galactosidase, $\beta$-galactosidase, $\alpha$-glucosidase, $\beta$-glucuronidase, $\beta$-glucosidase, $\alpha$-mannosidase and $\alpha$-fucosidase. Detailed fatty acid profiles are given in the text; major fatty acids are as given in the genus description. The pigments are characterized by absorption peaks at 390 and $455 \mathrm{~nm}$ with a shoulder at $427 \mathrm{~nm}$ for strain $\mathrm{KMM} 3891^{\mathrm{T}}$ and an absorption peak at $407 \mathrm{~nm}$ only for strain KMM 3892. Susceptible to (per disc) kanamycin $(30 \mu \mathrm{g})$, nalidixic acid $(30 \mu \mathrm{g})$, neomycin $(30 \mu \mathrm{g})$, ofloxacin $(5 \mu \mathrm{g})$, polymyxin (300 U), erythromycin $(15 \mu \mathrm{g})$ and chloramphenicol $(30 \mu \mathrm{g})$ and resistant to benzylpenicillin $(10 \mathrm{U})$, carbenicillin $(100 \mu \mathrm{g})$, oxacillin $(10 \mu \mathrm{g})$, tetracycline $(30 \mu \mathrm{g})$, cephazolin $(30 \mu \mathrm{g})$ and cephalexin $(30 \mu \mathrm{g})$. Susceptibility to ampicillin $(10 \mu \mathrm{g})$, gentamicin $(10 \mu \mathrm{g})$, lincomycin $(15 \mu \mathrm{g})$, oleandomycin $(15 \mu \mathrm{g})$, rifampicin $(5 \mu \mathrm{g})$ and streptomycin $(30 \mu \mathrm{g})$ is strain-dependent: KMM $3891^{\mathrm{T}}$ is susceptible and KMM 3892 is resistant. Strain KMM 3892 is susceptible to vancomycin $(30 \mu \mathrm{g})$, whereas KMM $3891^{\mathrm{T}}$ is resistant.

The type strain, KMM $3891^{\mathrm{T}}\left(=\mathrm{NRIC} 0753^{\mathrm{T}}=\mathrm{JCM} 15738^{\mathrm{T}}\right)$, and reference strain KMM 3892 were isolated from the marine mollusc Umbonium costatum (Gastropoda, Trochidae), collected from the southern coast of the Sea of Japan, Russia.

\section{Acknowledgements}

This study was supported by a grant from the Russian Foundation for Basic Research (RFBR) and the Far-Eastern Branch of Russian Academy of Sciences 06-04-96007 and by a grant from the Presidium of RAS 'Molecular and Cell Biology'.

\section{References}

Baumann, P. \& Baumann, L. (1981). The marine Gram-negative eubacteria: genera Photobacterium, Beneckea, Alteromonas, Pseudomonas and Alcaligenes. In The Prokaryotes, vol. 1, pp. 13021330. Edited by M. P. Starr, H. Stolp, H. G. Trüper, A. Balows \& H. Schlegel. Berlin: Springer.

Blackall, L. L., Hayward, A. C. \& Sly, L. I. (1985). Cellulolytic and dextranolytic gram-negative bacteria: revival of the genus Cellvibrio. J Appl Bacteriol 59, 81-97.

Bligh, E. G. \& Dyer, W. J. (1959). A rapid method of total lipid extraction and purification. Can J Biochem Physiol 37, 911-917.

Distel, D. L., Morrill, W., MacLaren-Toussaint, N., Franks, D. \& Waterbury, J. (2002). Teredinibacter turnerae gen. nov., sp. nov., a dinitrogen-fixing, cellulolytic, endosymbiotic $\gamma$-proteobacterium isolated from the gills of wood-boring molluscs (Bivalvia: Teredinidae). Int J Syst Evol Microbiol 52, 2261-2269.

Ekborg, N. A., Gonzalez, J. M., Howard, M. B., Taylor, L. E., Hutcheson, S. W. \& Weiner, R. M. (2005). Saccharophagus degradans gen. nov., sp. nov., versatile marine degrader of complex polysaccharides. Int J Syst Evol Microbiol 55, 1545-1549.

Ezaki, T., Hashimoto, Y. \& Yabuuchi, E. (1989). Fluorometric deoxyribonucleic acid-deoxyribonucleic acid hybridization in microdilution wells as an alternative to membrane filter hybridization in which radioisotopes are used to determine genetic relatedness among bacterial strains. Int J Syst Bacteriol 39, 224-229.

Gerhardt, P., Murray, R. G. E., Wood, W. A. \& Krieg, N. R. (editors) (1994). Methods for General and Molecular Bacteriology. Washington, DC: American Society for Microbiology.

Gonzalez, J. M. \& Weiner, R. M. (2000). Phylogenetic characterization of marine bacterium strain 2-40, a degrader of complex polysaccharides. Int J Syst Evol Microbiol 50, 831-834.

Gonzalez, J. M., Mayer, F., Moran, A., Hodson, R. E. \& Whitman, W. (1997). Microbulbifer hydrolyticus gen. nov., sp. nov., and Marinobacterium georgiense gen. nov., sp. nov., two marine bacteria from a lignin-rich pulp mill waste enrichment community. Int J Syst Bacteriol 47, 369-376.

Humphry, D. R., Black, G. W. \& Cummings, S. P. (2003). Reclassification of 'Pseudomonas fluorescens subsp. cellulosa' NCIMB 10462 (Ueda et al. 1952) as Cellvibrio japonicus sp. nov. and revival of Cellvibrio vulgaris sp. nov., nom. rev. and Cellvibrio fulvus sp. nov., nom. rev. Int J Syst Evol Microbiol 53, 393-400.

Kurahashi, M. \& Yokota, A. (2007). Endozoicomonas elysicola gen. nov., sp. nov., a $\gamma$-proteobacterium isolated from the sea slug Elysia ornata. Syst Appl Microbiol 30, 202-206.

Leifson, E. (1963). Determination of carbohydrate metabolism of marine bacteria. J Bacteriol 85, 1183-1184.

Marmur, J. \& Doty, P. (1962). Determination of the base composition of deoxyribonucleic acid from its thermal denaturation temperature. J Mol Biol 5, 109-118.

Mergaert, J., Lednicka, D., Goris, J., Cnockaert, M. C., De Vos, P. \& Swings, J. (2003). Taxonomic study of Cellvibrio strains and description of Cellvibrio ostraviensis sp. nov., Cellvibrio fibrivorans sp. nov. and Cellvibrio gandavensis sp. nov. Int J Syst Evol Microbiol 53, 465-471.

Miyazaki, M., Nogi, Y., Ohta, Y., Hatada, Y., Fujiwara, Y., Ito, S. \& Horikoshi, K. (2008). Microbulbifer agarilyticus sp. nov. and Microbulbifer thermotolerans sp. nov., agar-degrading bacteria isolated from deep-sea sediment. Int J Syst Evol Microbiol 58, 1128-1133.

Owen, R. J., Hill, L. R. \& Lapage, S. P. (1969). Determination of DNA base composition from melting profiles in dilute buffers. Biopolymers 7, 503-516. 
Pearson, W. R. \& Lipman, D. J. (1988). Improved tools for biological sequence comparison. Proc Natl Acad Sci U S A 85, 2444-2448.

Romanenko, L. A., Schumann, P., Zhukova, N. V., Rohde, M., Mikhailov, V. V. \& Stackebrandt, E. (2003). Oceanisphaera litoralis gen. nov., sp. nov., a novel halophilic bacterium from marine bottom sediments. Int J Syst Evol Microbiol 53, 1885-1888.

Romanenko, L. A., Schumann, P., Rohde, M., Mikhailov, V. V. \& Stackebrandt, E. (2004). Reinekea marinisedimentorum gen. nov., sp. nov., a novel gammaproteobacterium from marine coastal sediments. Int J Syst Evol Microbiol 54, 669-673.

Romanenko, L. A., Uchino, M., Falsen, E., Frolova, G. M., Zhukova, N. V. \& Mikhailov, V. V. (2005). Pseudomonas pachastrellae sp. nov., isolated from a marine sponge. Int J Syst Evol Microbiol 55, 919-924.

Romanenko, L. A., Uchino, M., Frolova, G. M., Tanaka, N., Kalinovskaya, N. I., Latyshev, N. \& Mikhailov, V. V. (2007). Sphingomonas molluscorum sp. nov., a novel marine isolate with antimicrobial activity. Int J Syst Evol Microbiol 57, 358-363.

Shida, O., Takagi, H., Kadowaki, K., Nakamura, L. K. \& Komagata, K. (1997). Transfer of Bacillus alginolyticus, Bacillus chondroitinus, Bacillus curdlanolyticus, Bacillus glucanolyticus, Bacillus kobensis, and Bacillus thiaminolyticus to the genus Paenibacillus and emended description of the genus Paenibacillus. Int J Syst Bacteriol 47, 289-298.

Shieh, W. Y., Liu, T. Y., Lin, S. Y., Jean, W. D. \& Chen, J. S. (2008). Simiduia agarivorans gen. nov., sp. nov., a marine, agarolytic bacterium isolated from shallow coastal water from Keelung, Taiwan. Int J Syst Evol Microbiol 58, 895-900.

Smibert, R. M. \& Krieg, N. R. (1994). Phenotypic characterization. In Methods for General and Molecular Bacteriology, pp. 607-654. Edited by P. Gerhardt, R. G. E. Murray, W. A. Wood \& N. R. Krieg. Washington, DC: American Society for Microbiology.

Tamura, K., Dudley, J., Nei, M. \& Kumar, S. (2007). MEGA 4: molecular evolutionary genetics analysis (MEGA) software version 4.0. Mol Biol Evol 24, 1596-1599.
Tang, S. K., Wang, Y., Cai, M., Lou, K., Mao, P. H., Jin, X., Jiang, C. L., Xu, L. H. \& Li, W. J. (2008). Microbulbifer halophilus sp. nov., a moderately halophilic bacterium from north-west China. Int J Syst Evol Microbiol 58, 2036-2040.

Thompson, J. D., Gibson, T. J., Plewniak, F., Jeanmougin, F. \& Higgins, D. G. (1997). The CLUSTAL_X windows interface: flexible strategies for multiple sequence alignment aided by quality analysis tools. Nucleic Acids Res 25, 4876-4882.

Vaskovsky, V. E. \& Terekhova, T. A. (1979). HPTLC of phospholipid mixtures containing phosphatidylglycerol. J High Resolut Chromatogr 2, 671-672.

Venkateswaran, K., Moser, D. P., Dollhopf, M. E., Lies, D. P., Saffarini, D. A., MacGregor, B. J., Ringelberg, D. B., White, D. C., Nishijima, M. \& other authors (1999). Polyphasic taxonomy of the genus Shewanella and description of Shewanella oneidensis sp. nov. Int J Syst Bacteriol 49, 705-724.

Wayne, L. G., Brenner, D. J., Colwell, R. R., Grimont, P. A. D., Kandler, O., Krichevsky, M. I., Moore, L. H., Moore, W. E. C., Murray, R. G. E. \& other authors (1987). International Committee on Systematic Bacteriology. Report of the ad hoc committee on reconciliation of approaches to bacterial systematics. Int J Syst Bacteriol 37, 463-464.

Yoon, J.-H., Kim, I.-G., Shin, D.-Y., Kang, K. H. \& Park, Y.-H. (2003a). Microbulbifer salipaludis sp. nov., a moderate halophile isolated from a Korean salt marsh. Int J Syst Evol Microbiol 53, 53-57.

Yoon, J.-H., Kim, H., Kang, K. H., Oh, T.-K. \& Park, Y.-H. (2003b). Transfer of Pseudomonas elongata Humm 1946 to the genus Microbulbifer as Microbulbifer elongatus comb. nov. Int J Syst Evol Microbiol 53, 1357-1361.

Yoon, J.-H., Kim, I.-G., Oh, T.-K. \& Park, Y.-H. (2004). Microbulbifer maritimus sp. nov., isolated from an intertidal sediment from the Yellow Sea, Korea. Int J Syst Evol Microbiol 54, 1111-1116.

Yoon, J. H., Jung, S. Y., Kang, S. J. \& Oh, T. K. (2007). Microbulbifer celer sp. nov., isolated from a marine solar saltern of the Yellow Sea in Korea. Int J Syst Evol Microbiol 57, 2365-2369. 